\title{
Life Cycle of Heterodera glycines in Resistant and Susceptible Soybean
}

\author{
Fernando Godinho de Araújo ${ }^{1}$, Rodrigo Marques Ferrari ${ }^{2}$, Juliana de Oliveira Silva ${ }^{2}$, \\ Janaina Alves de Almeida Moreira ${ }^{2}$ \& Mara Rúbia da Rocha ${ }^{2}$ \\ ${ }^{1}$ Instituto Federal Goiano, Campus Urutaí, Urutaí, GO, Brazil \\ ${ }^{2}$ Escola de Agronomia, Universidade Federal de Goiás, Campus Samambaia, Goiânia, GO, Brazil \\ Correspondence: Fernando Godinho de Araújo, Instituto Federal Goiano, Campus Urutaí, Rodovia Geraldo Silva \\ do Nascimento, Km 2.5, CEP: 75790-000, Urutaí, GO, Brazil. Tel: 55-643-465-1973. E-mail: \\ godinhoaraujo@hotmail.com
}

Received: September 23, 2018

Accepted: November 8, 2018

Online Published: January 15, 2019

doi:10.5539/jas.v11n2p507

URL: https://doi.org/10.5539/jas.v11n2p507

\begin{abstract}
The life cycle of the soybean cyst nematode lasts approximately $21-24$ days at temperatures ranging from $23{ }^{\circ} \mathrm{C}$ to $25^{\circ} \mathrm{C}$. Mean temperatures above $25^{\circ} \mathrm{C}$ are often found in Goiás State and in other Brazilian regions. Thus, the aim of the present study is to assess the penetration and cycle duration of Heterodera glycines Type $0^{-}$(race 3) in nematode-resistant and susceptible soybean cultivars grown in greenhouse under controlled conditions. The study was conducted at soil temperatures ranging from $23.9^{\circ} \mathrm{C}$ to $31.1^{\circ} \mathrm{C}$ using two soybean cultivars that were assessed in ten different periods; each assessment was conducted in six plants. The herein used soybean cultivars were BRS Valiosa RR and BRSGO 8860RR, which were, respectively, susceptible and resistant to the nematode. Root staining assessments were performed 2, 4, 6, 9, 12, 15, 18, 21, 24 and 30 days after inoculation (DAI). Besides the root staining assessments, the females and eggs were also assessed through extraction using the sieving and flotation method, at the $30^{\text {th }}$ DAI. Heterodera glycines $\mathrm{J} 2$ penetration was similar in both the susceptible and the resistant cultivars throughout the assessment period. It indicates that the nematode penetration was not affected by resistance. The Heterodera glycines cycle at soil temperature ranging from $23.9^{\circ} \mathrm{C}$ to $31.1{ }^{\circ} \mathrm{C}$ and at room temperature ranging from $27.0^{\circ} \mathrm{C}$ to $36.3^{\circ} \mathrm{C}$ was complete in 15 days, in both the susceptible and the resistant cultivars. A similar number of $\mathrm{J} 2$ has penetrated the roots of both cultivars and greater penetration intensity was found from the $6^{\text {th }}$ to the $15^{\text {th }}$ DAI. The peak J3, J4 and female formation period in the resistant cultivar was later than that observed in the susceptible cultivar.
\end{abstract}

Keywords: Glycine max, genetic resistance, Heterodera glycines

\section{Introduction}

The nematode Heterodera glycines Ichinohe (1952), also known as soybean cyst nematode, is one of the main pathogens affecting soybean crops in the main countries producing this oilseed. This nematode was first detected in Brazil in the 1991/92 harvest (Lima et al., 1992; Lordello et al., 1992; Monteiro \& Morais, 1992). It is found in approximately 150 Brazilian counties, thus covering an area bigger than 3.0 million hectares (Dias et al., 2010).

The symptoms of this nematode attack appear in spatially clumped plants and, in many cases, the plants eventually die. The root system is reduced and gets infested with tiny Heterodera glycines females. When the female dies, its body turns into a hard structure called cyst, which dislodges from the root and stays in the soil. The dark brown cyst is filled with eggs and highly resistant to decay and desiccation. In the absence of a host plant, the cyst is able to survive in the soil for more than eight years (Lordello, 1984; Dias et al., 2010; Embrapa, 2011).

The life cycle of Heterodera glycines at soil temperatures ranging from $23{ }^{\circ} \mathrm{C}$ to $25^{\circ} \mathrm{C}$ lasts approximately $21-24$ days (Lauritis et al., 1983; Young, 1992). Thus, it is possible obtaining 4 to 5 nematode generations in a single growing cycle. The Brazilian climate conditions comprise temperature of approximately $28.7^{\circ} \mathrm{C}$ and allow the Heterodera glycines to complete its life cycle approximately 29 days after soil infestation. Thus, it is possible obtaining three to four nematode generations during the crop cycle (Cunha et al., 2008). 
Heterodera glycines depends on the formation of its feeding site (syncytium) in order to complete its life cycle, since syncytium is its only source of nutrients during parasitism (Van Der Eycken et al., 1996). However, syncytium only forms in cultivars susceptible to the nematode. The juveniles of cultivars resistant to Heterodera glycines are unable to set feeding sites due to syncytium deterioration, which takes place in few days and kills the nematode within the root tissue (Kim et al., 1987; Kim \& Riggs, 1992; Tylka, 2008).

The genetic basis of the resistance found in Brazilian soybean cultivars, which derive from North American cultivars, is relatively narrow. Since pathogens have high variability, they can easily overcome these cultivars resistance (Yue et al., 2000). Thus, the syncytium formation process is not always interrupted and adult females can be found in the root system of resistant cultivars (Young, 1992; Li et al., 2004; Brucker et al., 2005).

The aim of the present study is to assess the penetration and cycle duration of Heterodera glycines Type 0 (race 3 ) in resistant and susceptible soybean cultivars grown in greenhouse under controlled conditions, as a way to help better understanding the soybean cyst nematode behavior under Brazilian climate conditions.

\section{Method}

The study was conducted under greenhouse condition at the Agronomy School/UFG (16 $35^{\prime} 47.36^{\prime \prime} \mathrm{S}$, $49^{\circ} 16^{\prime} 48.01^{\prime \prime} \mathrm{W}$; altitude: 726 meters). The herein adopted experimental design was completely randomized and it used two soybean cultivars assessed in ten different assessment periods, with six repetitions.

Four seeds of soybean cultivars resistant to Heterodera glycines BRSGO 8860RR and susceptible to Heterodera glycines BRSGO Valiosa RR were seeded in previously autoclaved 0.3 liter-capacity ceramic pots containing a mixture of soil and sand at the ratio 1:1. Thinning was performed seven days after sowing and a single seedling remained in each pot. The inoculation was carried out after thinning, using a suspension containing 5,000 eggs and second-stage juveniles (J2) of Heterodera glycines Type $0^{-}$(race 3).

The inoculum was obtained in a naturally infested area in Campo Alegre County, Goiás State. The soil containing Heterodera glycines cysts was seeded with the susceptible soybean cultivar BRS Valiosa RR in order to multiply the inoculum in the greenhouse. The nematode was identified as race 3, according to Riggs and Schmitt (1988), before the experiment was conducted. The HG type was determined according to Niblack et al. (2002) and the population was classified as HG Type 0 .

The assessments were performed 2, 4, 6, 9, 12, 15, 18, 21, 24 and 30 days after inoculation (DAI) by observing the Heterodera glycines penetration and development in the root system. Besides these assessments, which were performed using the root staining technique, the number of females and eggs was also assessed through root extraction.

After the technique by Byrd et al. (1983) was adapted, the soybean plant roots were stained to assess the nematode penetration and development. The root systems were fragmented into pieces of approximately two centimeters, after previous sterilization. These fragments were soaked in $1.5 \% \mathrm{NaOCl}$ solution for four minutes. Next, they were drained and washed in order to remove all the sodium hypochlorite, and soaked in water for fifteen minutes. Subsequently, $1 \mathrm{~mL}$ dye was added to $30 \mathrm{~mL}$ water and the material was boiled. The dye was prepared by diluting $3.5 \mathrm{~g}$ acid fuchsin in $250 \mathrm{~mL}$ acetic acid and $750 \mathrm{~mL}$ distilled water. After boiling for approximately thirty seconds, the root fragments were drained, allowed to cool in order to avoid the formation of bubbles within the root tissue, and rinsed in running water to remove dye excess. Then, they were lightened in acidified glycerol with three drops of hydrochloric acid and boiled again. After the lightening process, the fragments were placed in glycerin and stored in the refrigerator, until they were mounted on slides.

At the time of the $10^{\text {th }}$ assessment - the $30^{\text {th }}$ DAI - six replications of each cultivar were used to assess the females in the root systems, according to the method described by Tihohod (2000). A strong waterjet was released over a set of 20- and 60-mesh sieves. The material retained in the 20-mesh sieve was discarded and that retained in the 60-mesh sieve was collected and filtered through filter paper on a screened gutter (Andrade et al., $1995)$ and then transferred to a stereomicroscope $(15 \times$ magnification) in order to count the number of females. After quantification, ten females were randomly separated and severed in a 100 -mesh sieve placed over a 400 -mesh one. The eggs retained in the 400 -mesh sieve were placed in a $50 \mathrm{~mL}$ beaker. The suspension was homogenized and the eggs were quantified under optical microscope (50x magnification) using Peters' counting slides.

The number of second (J2), third (J3) and fourth (J4) stage juveniles, as well as the number of females in the roots, was counted in each assessment using the staining technique. In order to do so, all stained root fragments were placed in Petri dishes, which were transferred to a stereomicroscope (M 205: 7.8 $\times$ to $160 \times$ magnification) for counting. 
Daily readings of maximum and minimum temperatures were performed during the experiment in the greenhouse using a digital thermometer, which measures internal (soil) and external (environment) temperatures with $0.1^{\circ} \mathrm{C}$ resolution.

The data were subjected to analysis of variance in the SISVAR software (Ferreira, 2000) and the means were compared through the Scott-Knott test at 5\% probability. All the data were transformed into $\sqrt{x+1}$ in order to perform the analysis.

\section{Results and Discussion}

The mean temperature in the soil during the experiment was $26.6{ }^{\circ} \mathrm{C}$ and it ranged from $23{ }^{\circ} \mathrm{C}$ to $31{ }^{\circ} \mathrm{C}$. On the other hand, the mean temperature in the environment was $32{ }^{\circ} \mathrm{C}$ and it ranged from $26.4{ }^{\circ} \mathrm{C}$ to $40.1{ }^{\circ} \mathrm{C}$ (Figure 1).

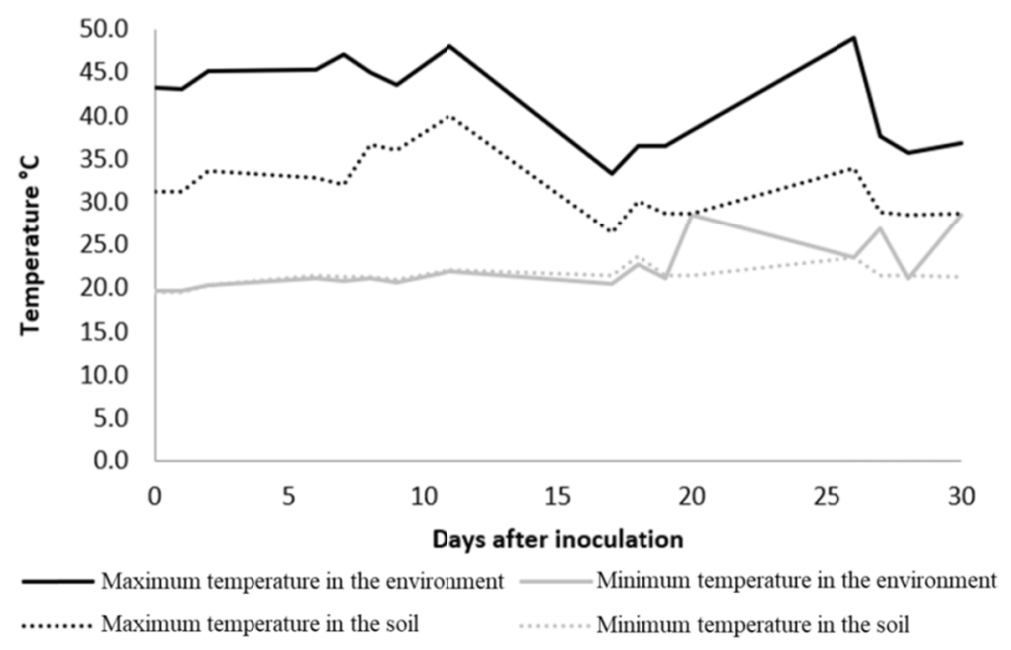

Figure 1. Maximum and minimum temperatures in the environment and in the soil during the experiment

The environmental temperature has not directly affected the nematode. However, as it increased, the soil temperature tended to increase and, therefore, affect the nematode cycle. The optimum embryogenesis temperature that leads to less nematode mortality is $24{ }^{\circ} \mathrm{C}$ and the egg hatching takes place at temperatures ranging from $20{ }^{\circ} \mathrm{C}$ to $30{ }^{\circ} \mathrm{C}$ (Alston \& Schmitt, 1988). Since the mean temperature during the experiment was approximately $26.6^{\circ} \mathrm{C}$, it was within the range that does not affect nematode development and allows it to complete its cycle. However, it might have influenced the results found in the current study.

The highest $\mathrm{J} 2$ concentration was found in the assessment performed at the $9^{\text {th }}$ DAI (Table 1). However, higher penetration rates were found between the $6^{\text {th }}$ and $15^{\text {th }}$ DAI, thus indicating that the eggs and the $\mathrm{J} 2 \mathrm{kept}$ high viability until the $15^{\text {th }}$ DAI. There was a sharp decrease in the number of $\mathrm{J} 2$ found in the roots from the $15^{\text {th }}$ to the $30^{\text {th }}$ the DAI (Table 1 and Figure 2). 
Table 1. Mean number of Heterodera glycines (race 3) J2 and J3 per root system of the soybean cultivars BRS Valiosa RR and BRSGO 8860RR, which were, respectively, susceptible and resistant to the nematode, in 10 different days after inoculation (DAI). Goiânia, GO, 2012

\begin{tabular}{|c|c|c|c|c|c|c|c|c|}
\hline \multirow{3}{*}{$\frac{\text { DAI }}{2}$} & \multicolumn{4}{|c|}{$\mathrm{J} 2$} & \multicolumn{4}{|c|}{$\mathrm{J} 3$} \\
\hline & \multirow{2}{*}{$\begin{array}{l}\text { Valiosa } \\
2.0\end{array}$} & \multirow{2}{*}{$\begin{array}{l}8860 \\
0.2\end{array}$} & \multicolumn{2}{|c|}{ Average* } & \multirow{2}{*}{$\begin{array}{l}\text { Valiosa } \\
0.0\end{array}$} & \multirow{2}{*}{$\begin{array}{l}8860 \\
0.0\end{array}$} & \multicolumn{2}{|c|}{ Average* } \\
\hline & & & 0.9 & $\mathrm{a}$ & & & 0.0 & $\mathrm{a}$ \\
\hline 4 & 17.0 & 37.3 & 27.0 & $\mathrm{~b}$ & 0.0 & 0.0 & 0.0 & $\mathrm{a}$ \\
\hline 6 & 179.0 & 225.0 & 202.1 & d & 4.3 & 9.2 & 6.8 & $\mathrm{~b}$ \\
\hline 9 & 249.0 & 370.4 & 309.6 & $\mathrm{e}$ & 24.0 & 17.8 & 20.9 & $\mathrm{c}$ \\
\hline 12 & 162.0 & 223.9 & 192.8 & d & 35.0 & 45.1 & 40.1 & $\mathrm{c}$ \\
\hline 15 & 223.0 & 266.0 & 244.5 & $\mathrm{~d}$ & 108.0 & 54.5 & 81.3 & $\mathrm{~d}$ \\
\hline 18 & 19.0 & 32.0 & 25.5 & $\mathrm{~b}$ & 26.8 & 17.0 & 21.9 & $\mathrm{c}$ \\
\hline 21 & 46.0 & 108.5 & 77.3 & $\mathrm{c}$ & 28.0 & 39.0 & 33.5 & $\mathrm{c}$ \\
\hline 24 & 16.0 & 18.8 & 17.3 & $\mathrm{~b}$ & 12.2 & 18.5 & 15.3 & $\mathrm{~b}$ \\
\hline 30 & 8.0 & 25.3 & 16.8 & $\mathrm{~b}$ & 8.5 & 15.2 & 11.8 & $\mathrm{~b}$ \\
\hline Average & 92.0 & 130.7 & & & 24.7 & 21.6 & & \\
\hline $\mathrm{CV}(\%)$ & 34.98 & & & & 47.53 & & & \\
\hline
\end{tabular}

Note. * Original data and statistics performed through data transformed into $\sqrt{x+1}$. Means followed by the same letters did not statistically differ from each other (Scott-Knott, $\mathrm{P}<0.05$ ).
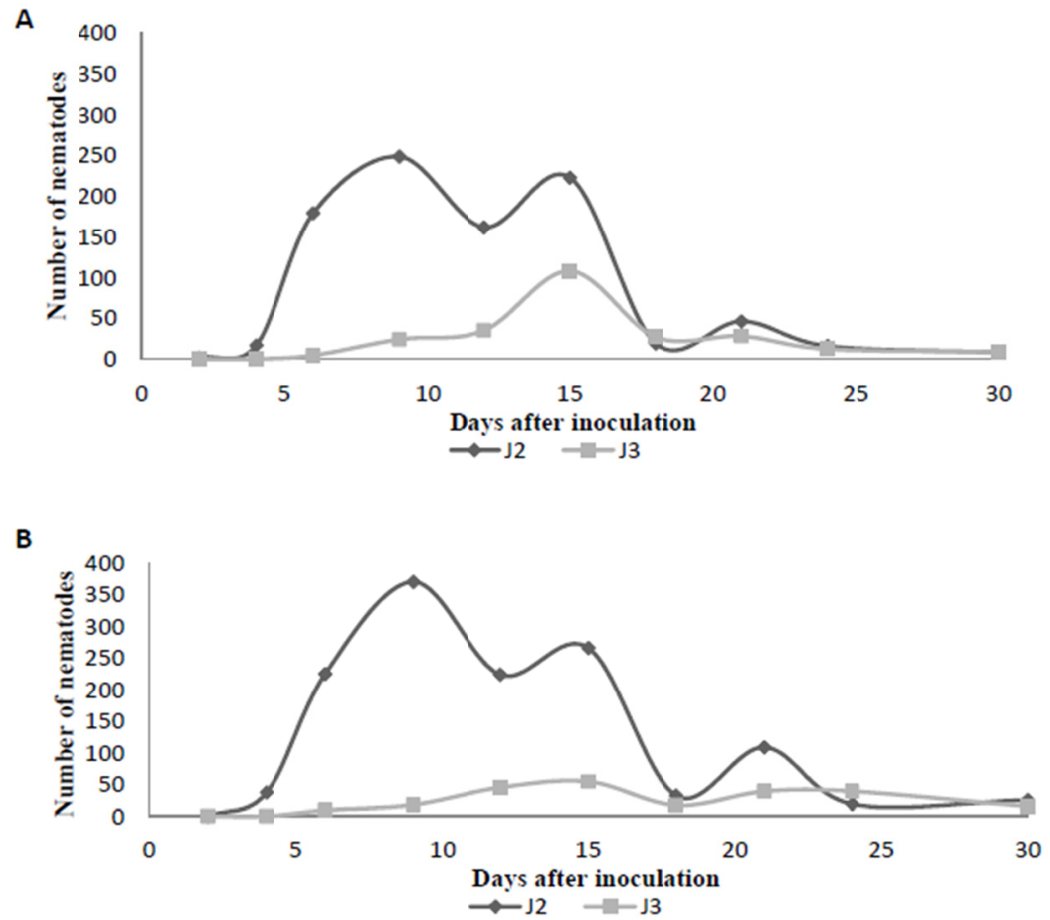

Figure 2. Average number of J2 and J3 of Heterodera glycines per root system of susceptible soybean cultivars, BRS Valiosa RR (A), and resistant BRS 8860 RR (B), in ten evaluations performed after inoculation

Although there was aggressive penetration at the $21^{\text {st }}$ DAI, this decrease suggests that these $\mathrm{J} 2$ derived from females formed in the roots, i.e., they were second-generation nematodes. In fact, it may be confirmed by observing the females in the roots of both cultivars at the $15^{\text {th }}$ DAI (Table 2). 
Table 2. Mean number of Heterodera glycines (race 3) J4 and females per root system of the soybean cultivars BRS Valiosa RR and BRSGO 8860RR, which were, respectively, susceptible and resistant to the nematode, in 10 different days after inoculation (DAI). Goiânia, GO, 2012

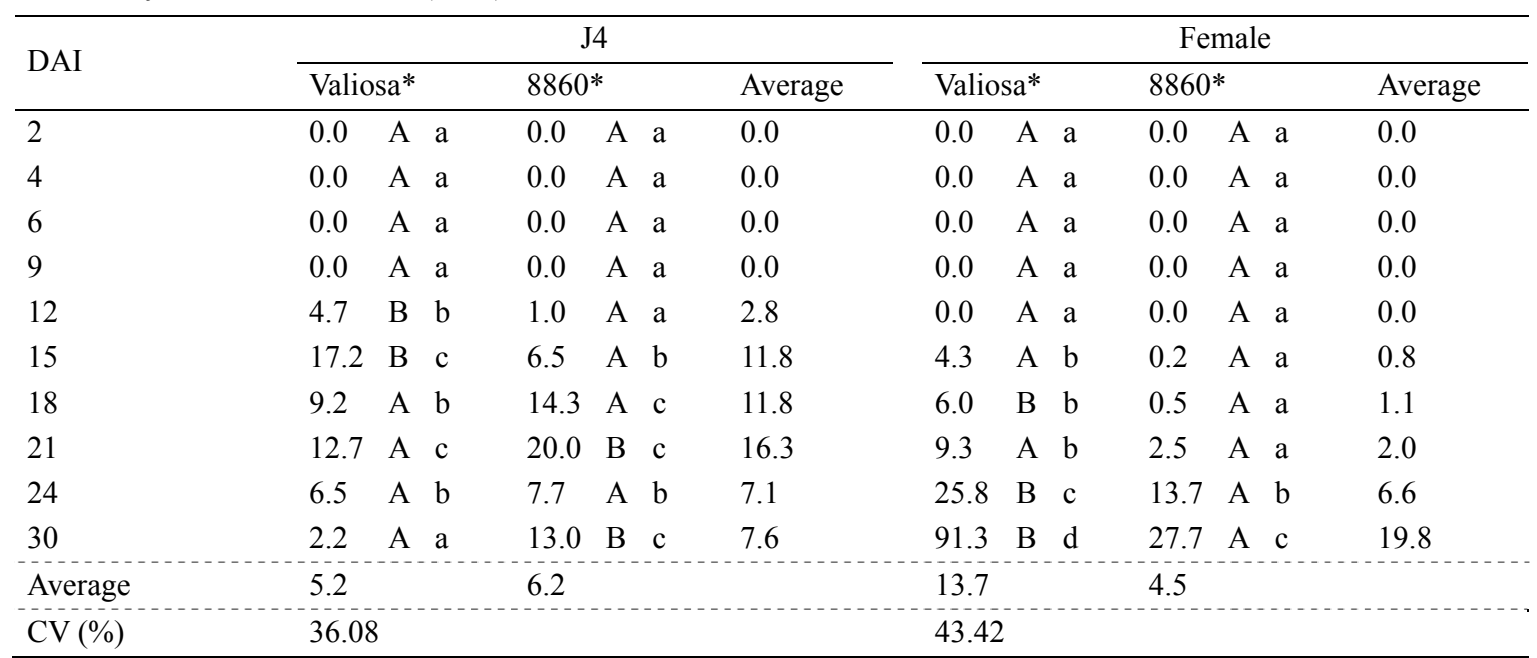

Note. * Original data and statistics performed through data transformed into $\sqrt{x+1}$. Means followed by the same lowercase letters in the column and capital letters in the line did not statistically differ from each other (Scott-Knott, $\mathrm{P}<0.05$ ).

It is worth highlighting that the penetration was similar in both cultivars, and it indicated that the resistance to the soybean cyst nematode has manifested just after penetration (Table 1). It corroborates the results found by Acedo et al. (1984), and Asmus et al. (2001), who have assessed the Heterodera glycines penetration in resistant and susceptible soybean cultivars and concluded that juveniles equally penetrate both cultivars.

The third-stage juveniles (J3) were identified in the assessment carried out at the $6^{\text {th }}$ DAI; however, the highest $\mathrm{J} 3$ concentration was found in the assessment carried out at the $15^{\text {th }} \mathrm{DAI}$, in both the resistant and the susceptible cultivars, although the resistant cultivar values were lower (Figure 2 and Table 1). The J3 formation in the resistant cultivar (Figure 2B) indicates that the hypersensitive reaction did not occur immediately after the inoculation and that it did not prevent the initial nematode establishment. Instead, the initial responses to the soybean cyst nematode infection were similar to those of the susceptible cultivars. According to Kim et al. (1987), and Kim and Riggs (1992), the syncytia are formed in the roots within approximately 42 hours after inoculation. As the infection progresses, the hypersensitivity reaction takes place. Approximately five days after the inoculation, the nucleus of the syncytium cells presents large masses of agglutinated chromatin and disintegrates. After nucleus disintegration, the cytoplasm degenerates and it eliminates the nutrient source of the nematode, which dies from starvation. Thus, the nematode keeps on developing as long as the hypersensitivity reaction is not complete.

The fourth-stage juveniles (J4) were found from the $12^{\text {th }}$ DAI on (Table 2). The highest $\mathrm{J} 4$ concentration was found in the BRS Valiosa RR cultivar at the $15^{\text {th }}$ DAI (Figure 3A) and in the BRSGO 8860RR cultivar at the $21^{\text {st }}$ DAI (Figure 3B). Heterodera glycines females were found in the soybean roots from the $15^{\text {th }}$ DAI on (Table 2). From the $15^{\text {th }} \mathrm{DAI}$ on, the number of females found in the roots of both cultivars has increased until the $30^{\text {th }} \mathrm{DAI}$, although the amount found in the roots of the susceptible cultivar-BRS Valuable RR - was much higher than that found in the resistant cultivar-BRSGO 8860RR (Figure 3). 

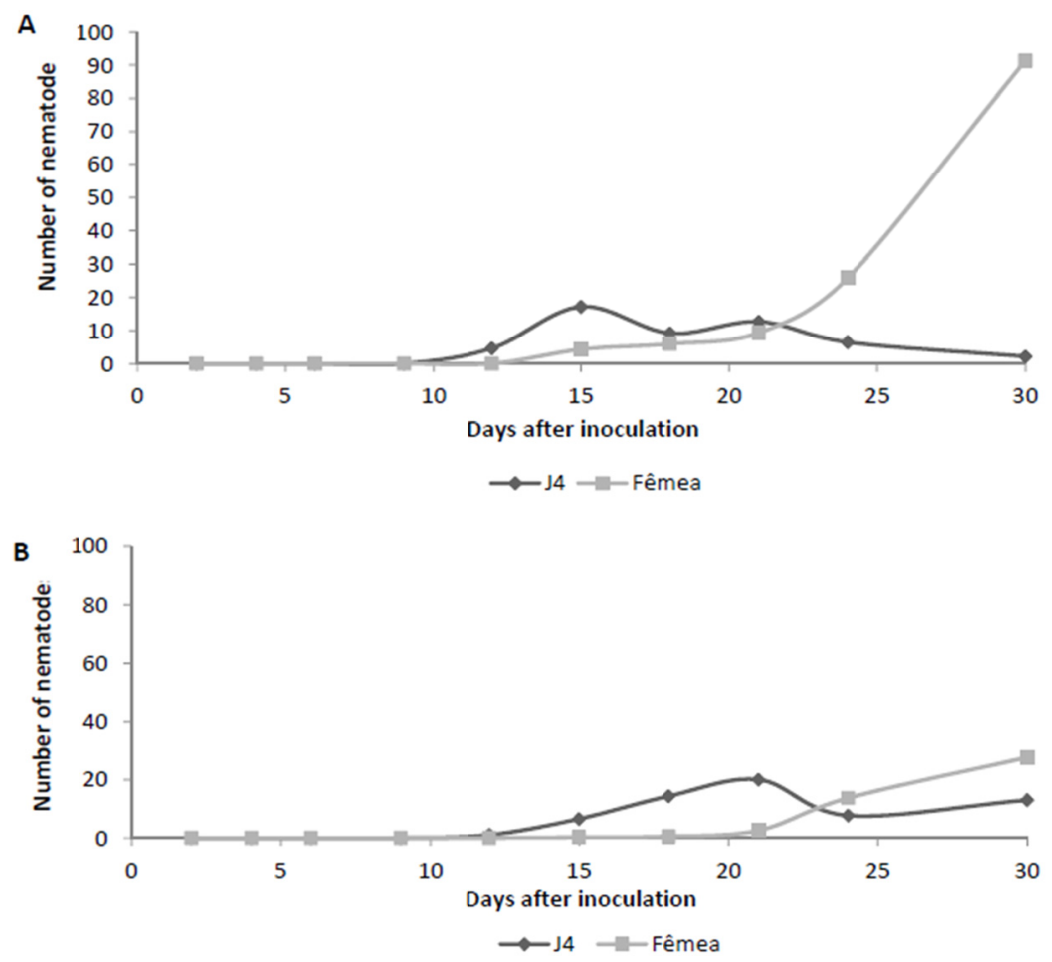

Figure 3. Mean number of Heterodera glycines $\mathrm{J} 4$ and females in the roots of the susceptible soybean cultivar BRS Valiosa RR (A), and of the resistant cultivar BRSGO 8860RR (B), in ten assessments carried out after inoculation

The extraction of females using the traditional method (Tihohod, 2000) was held at the $30^{\text {th }}$ DAI. The highest number of total females and of females per root gram was found in the susceptible soybean cultivar (Table 3). However, the presence of females in the resistant cultivar roots, even at low numbers, shows that the resistance of this cultivar is not complete. The number of eggs per female has shown no difference between cultivars (Table $3)$.

Table 3. Total number of females per root system, of females per root gram, and of eggs per female in the soybean cultivars BRS Valiosa RR and BRSGO 8860RR, which were, respectively, susceptible and resistant to Heterodera glycines (race 3). Goiânia, GO, 2012

\begin{tabular}{|c|c|c|c|}
\hline Cultivar & Female* & Female/g Root* & Egg/Female* \\
\hline Valiosa & $171.333 \mathrm{~b}$ & $183.5 \quad b$ & 50 \\
\hline 8860 & $9.167 \quad \mathrm{a}$ & $12.333 \mathrm{a}$ & 42 \\
\hline $\mathrm{CV}(\%)$ & 34.64 & 36.42 & 25.43 \\
\hline
\end{tabular}

Note. * Original data and statistics performed through data transformed into $\sqrt{x+1}$. Means followed by the same letters did not statistically differ from each other (Scott-Knott, $\mathrm{P}<0.05$ ).

The resistance source of the BRSGO 8860RR cultivar is the PI 88788, which provides a resistance less stable than that provided by the PI 437654 . The cultivar resistance to Heterodera glycines is strongly associated with the presence of the rhgl gene. However, there are functional differences in the alleles linked to rhgl. The alleles linked to the PI 437654 resistance gene provide resistance higher than that provided by the alleles linked to PI 88788 (Brucker et al., 2005). In addition, it is worth emphasizing that the nematode Heterodera glycines has great genetic variability. Thus, the resistance sources are not often available to all individuals in the population (Young, 1992).

By observing the nematode cycle (Figures 2 and 3), it was possible inferring that there was less $\mathrm{J} 3$ and $\mathrm{J} 4$ development in the resistant cultivar roots or even a development delay. However, by analyzing the data in Tables 1 and 2, which have originated the aforementioned Figures, it was possible concluding that the total 
number of $\mathrm{J} 3$ and $\mathrm{J} 4$ was similar in both cultivars and that there was no Heterodera glycines development delay in the roots of the BRSGO 8860RR cultivar. In fact, it was possible seeing a change in the period of highest J3 and $\mathrm{J} 4$ nematode formation. Thus, the number of $\mathrm{J} 3$ in the roots of the resistant cultivar was larger than that found in the roots of the susceptible cultivar in the assessments conducted at the $21^{\text {st }}, 24^{\text {th }}$ and $30^{\text {th }}$ DAI. On the other hand, the number of J4 was larger than that found in the susceptible cultivar in the assessments conducted at the $18^{\text {th }}, 21^{\text {st }}, 24^{\text {th }}$ and $30^{\text {th }}$ DAI. However, the formation of females was always lower in the resistant cultivar.

It is not possible saying that there was Heterodera glycines development delay in the resistant cultivar roots because $\mathrm{J} 3$, $\mathrm{J} 4$ and females were found in the roots of both cultivars in the same assessment periods, i.e., at the $6^{\text {th }}, 12^{\text {th }}$ and $15^{\text {th }}$ DAI, respectively. However, the numbers were smaller in the resistant cultivar when they were first found (Table 2).

By observing the results of the females in the assessment conducted at the $30^{\text {th }}$ DAI using the staining and the traditional extraction methods, it was possible seeing that the extraction method allowed quantifying a larger number of females. The traditional extraction method has led to a larger number of females in the susceptible cultivar, as well as to a smaller number of them in the resistant cultivar, in comparison to the staining method. This difference probably due to the non-extraction of females in the case of the resistant cultivar or to the loss of females in the case of the susceptible one. According to the staining method by Byrd et al. (1983), the soybean roots are washed with running water to remove substrate excess. Then, they are allowed to rest in a sodium hypochlorite solution. Many females may be lost in this handling, since they easily detach from the roots. This fact has probably occurred in the susceptible cultivar-BRS Valiosa RR - and it explains the counting of fewer females in comparison to that of the traditional extraction method. On the other hand, although the extraction technique involving the strong waterjet and the sieving has effectively extracted the females adhered to the roots, it could not extract the females inside the root tissue. Thus, it is likely that due to the lower development of females in the resistant cultivar, they may be retained within the root tissue and are not likely to be extracted through the traditional assessment method. However, they are likely to be quantified through the staining technique, which explains the larger number of females counted in the resistant cultivar-BRSGO 8860 $\mathrm{RR}$ - when this technique was applied.

By assessing the full nematode development according to its life cycle stage, it was possible seeing that Heterodera glycines (race 3 ) was able to complete its life cycle in both cultivars at the $15^{\text {th }}$ DAI, although the smallest number of females was found in the resistant cultivar. Interestingly, although the BRSO 8860RR cultivar was resistant to the nematode, it allowed the nematode to complete its life cycle.

Cunha et al. (2008) have assessed the life cycle of Heterodera glycines (race 9) under Maranhão State climate conditions and concluded that it was complete 29 days after nematode inoculation in the soil, at mean soil temperature $28.7^{\circ} \mathrm{C}$. Since penetration was not assessed, it was not possible knowing for sure how long $\mathrm{J} 2$ took to penetrate the roots. Consequently, it was not possible knowing the exact length of the nematode cycle; thus, it was estimated.

It was possible seeing $\mathrm{J} 2$ in all assessments, which makes it clear that the Heterodera glycines penetration was consistent in the roots of the two soybean cultivars and indicates that the penetrations occurred after the $15^{\text {th }}$ DAI were done by $\mathrm{J} 2$ derived from the second-generation nematode. Another factor concerns the identification of all Heterodera glycines cycle phases in the root system of the resistant soybean cultivar-BRSGO 8860RR. This result proves that the nematode was able to complete its life cycle in the resistant cultivar, and it also demonstrates the possible genetic variability of the pathogen. It corroborates the results found by Li et al. (2004), Brucker et al. (2005), and Fagihi et al. (2008), who showed that the resistance provided by the rghl gene originated from PI 88788 is not complete.

According to the conditions of the herein developed experiment, Heterodera glycines (race 3) was able to complete its life cycle at the $15^{\text {th }}$ DAI, although the population peak occurred at the $30^{\text {th }}$ DAI. It is quite disturbing from the population management viewpoint, since the nematodes were already in the soil when the soybean was seeded in the field. By considering the different maturity groups of planted soybean cultivars, which range approximately from 115 to 150 days, it would be possible obtaining from 7 to 10 nematode generations per crop cycle.

\section{Conclusion}

Heterodera glycines has completed its life cycle 15 days after the inoculation of the susceptible and resistant soybean cultivars, at mean temperature $26.6{ }^{\circ} \mathrm{C}$. 
The $\mathrm{J} 2$ penetration was similar in the susceptible cultivar and the highest intensity occurred between 6 and 15 days after inoculation.

The peak formation period of Heterodera glycines J3, J4 and females in the resistant cultivar roots occurred later than that of the susceptible cultivar.

\section{References}

Acedo, J. R., Dropkin, V. R., \& Luedders, V. D. (1984). Nematode population attrition and histopathology of Heterodera glycines soybean associations. Journal of Nematology, 16(1), 48-57.

Alston, D. G., \& Schmitt, D. P. (1988). Development of Heterodera glycines life stages as influenced by temperature. Journal of Nematology, 20(3), 366-372.

Andrade, P. J. M, Asmus, G. L., \& Silva, J. F. V. (1995). Um novo sistema para deteç̧ão e contagem de cistos de Heterodera glycines recuperados de amostras de solo. Fitopatologia Brasileira, 20, 358-358.

Asmus, G. L., Tomazzini, M. D. O., \& Ferraz, L. C. C. B. (2001). Penetração de Heterodera glycines em raízes de soja resistente. Nematologia Brasileira, 25(2), 251-253.

Brucker, E., Carlson, S., Wright, E., Niblack, T., \& Diers, B. (2005). Rhg1 alleles from soybean PI 437654 and PI 88788 respond differentially to isolates of Heterodera glycines in the greenhouse. Theoretical and Applied Genetics, 111(1), 44-49. https://doi.org/10.1007/s00122-005-1970-3

Byrd, D. W., Kirpatrick, T., \& Barker, K. R. (1983). An improved technique for clearing and staining plant tissue for detection of nematodes. Journal of Nematology, 15(1), 142-143.

Cunha, R. P., Maia, G. L., Rodacki, M. E. P., Silva, G. S., \& Meyer, M. C. (2008). Ciclo de vida de Heterodera glycines raça 9 em soja no Estado do Maranhão. Summa Phytopathologica, 34(3), 262-264. https://doi.org/10.1590/S0100-54052008000300012

Dias, W. P., Garcia, A., Silva, J. F. V., \& Carneiro, G. E. S. (2010). Nematóides em soja: Identificação e controle (p. 8). Comunicado Técnico. Londrina: Embrapa Soja.

EMBRAPA (Empresa Brasileira de Pesquisa Agropecuária). (2011). Tecnologias de Produção de Soja Região Central do Brasil 2012 e 2013. Sistemas de Produção 15 (p. 262). Londrina, Embrapa Soja. Retrieved from https://www.embrapa.br/busca-de-publicacoes/-/publicacao/904487/tecnologias-de-producao-de-soja---regi ao-central-do-brasil-2012-e-2013

Faghihi, J., Ferris, V., Donald, P., Noel, G., \& Welacky, T. (2008). Changes in resistance of PI88788 to field populations of soybean cyst nematode (SCN) (p. 235). The 5th Internetional Congress of Nematology.

Ferreira, D. F. (2000). Análises estatísticas por meio do Sisvar para Windows versão 4.0 (pp. 255-258). Reunião Anual da Região Brasileira da Sociedade Internacional de Biometria, 45, São Carlos. Programa e resumos... São Carlos: UFSCar.

Kim, K. S., \& Riggs, R. D. (1992). Cytopathological reactions of resistant soybean plants to nematode invasion. Biology and Management of the Soybean Cyst Nematode. St. Paul: APS Press.

Kim, Y. H., Riggs, R. D., \& Kim, K. S. (1987). Structural changes associated with resistance os soybean to Heterodera glycines. Journal of Nematology, 19(2), 177-187.

Lauritis, J. A., Rebois, R. V., \& Graney, I. S. (1983). Development of Heterodera glycines Ichinohe on soybean Glycine $\max$ (L.) Merr., under gnotobiotic conditions. Journal of Nematology, 15(2), 272-281.

Li, Y., Chen, S., \& Young, N. D. (2004). Effect of the $r g h 1$ gene on penetration, development and reproduction of Heterodera glycines race 3. Nematology, 6(5), 729-736. https://doi.org/10.1163/1568541042843522

Lima, R. D., Ferraz, S., \& Santos, J. M. (1992). Ocorrência de Heterodera sp. em soja no Triangulo Mineiro (Vol. 16, No. 81). Congresso Brasileiro de Nematologia. Resumos... Lavras: Sociedade Brasileira de Nematologia/Escola Superior de Agricultura de Lavras.

Lordello, A. I., Lordello, R. R. A., \& Quaggio, J. A. (1992). Heterodra sp. reduz produção de soja no Brasil (Vol. 16, No. 81). Congresso Brasileiro de Nematologia, Lavras. Resumos... Lavras: Sociedade Brasileira de Nematologia/Escola Superior de Agricultura de Lavras.

Lordello, L. G. E. (1984). Nematoides formadores de cistos (Gêneros Heterodera e Globodera). In L. G. E. Lordello (Ed.), Nematoides das plantas cultivadas (pp. 149-154). São Paulo: Nobel. 
Monteiro, A. R., \& Morais, S. R. A. C. (1992). Ocorrência do nematóide de cisto da soja, Heterodera glycines, Ichinohe, 1952, prejudicando a cultura da soja no Mato Grosso do Sul (Vol. 16, No. 82). Congresso Brasileiro de Nematologia, Lavras. Resumos... Lavras: Sociedade Brasileira de Nematologia/Escola Superior de Agricultura de Lavras.

Niblack, T. L., Arelli, P. R., Noel, G. R., Opperman, C. H., Orf, J. H., Schimitt, D. P., ... Tylka, G. L. (2002). A Revised Classification Scheme for Genetically Diverse Populations of Heterodera glycines. Journal of Nematology, 34(4), 279-288.

Riggs, R. D., \& Schimitt, D. P. (1988). Complete characterization of the race scheme for Heterodera glycines. Journal of Nematology, 20(3), 392-395.

Tihohod, D. (2000). Nematologia Agrícola Aplicada. Jaboticabal: FUNEP.

Tylka, G. L. (2008). Use of resistance for SCN management (pp. 11-14). $4^{\text {th }}$ National Soybean Nematode Conference, Tampa.

Van Der Eycken, W., Almeida Engler, J., Inze, D., Van Montagu, M., \& Gheysen, G. (1996). A molecular study of root-knot nematode induced feeding sites. Plant Journal: For Cell and Molecular Biology, 9(1), 45-54. https://doi.org/10.1046/j.1365-313X.1996.09010045.x

Young, L. D. (1992). Epiphytology and life cycle. In R. D. Riggs, \& J. A. Wrather (Eds.), Biology and management of the soybean cyst nematode (pp. 27-36). St. Paul: APS Press.

Yue, P., Sleper, D. A., \& Rao-Arelli, A. P. (2000). Genetic analysis of resistance to soybean cyst nematode in PI 438489B. Euphytica, 116(2), 181-186. https://doi.org/10.1023/A:1004054731652

\section{Copyrights}

Copyright for this article is retained by the author(s), with first publication rights granted to the journal.

This is an open-access article distributed under the terms and conditions of the Creative Commons Attribution license (http://creativecommons.org/licenses/by/4.0/). 